\title{
Physiological Quality of Swingle Citrumelo Seed after Refrigerated Storage of Fruits and Seeds
}

\author{
Marilia Morelli ${ }^{1}$, Fernando Alves de Azevedo ${ }^{1, * \mathbb{C}}$, Ana Julia Borim de Souza ${ }^{1}$, Rodrigo Martinelli ${ }^{1}[$ \\ and Patrícia Marluci da Conceição ${ }^{2}$ \\ 1 Centro de Citricultura Sylvio Moreira, Instituto Agronômico (IAC), Anhanguera Road, Km 158, \\ Cordeirópolis 13490-970, SP, Brazil; mariliamorelli90@gmail.com (M.M.); \\ anajuliaborim@gmail.com (A.J.B.d.S.); rdrg.martinelli@gmail.com (R.M.) \\ 2 Departamento de Desenvolvimento Rural, Centro de Ciências Agrárias, Universidade Federal de São Carlos, \\ Anhanguera Road, Km 174, Araras 13600-970, SP, Brazil; patymarluci@gmail.com \\ * Correspondence: fernando@ccsm.br
}

check for updates

Citation: Morelli, M.; Azevedo, F.A.d.; de Souza, A.J.B.; Martinelli, R.; da Conceição, P.M. Physiological Quality of Swingle Citrumelo Seed after Refrigerated Storage of Fruits and Seeds. Agriculture 2021, 11, 1243. https:/ / doi.org/10.3390/agriculture 11121243

Academic Editors: Georgios Tsaniklidis and Dimitrios Fanourakis

Received: 23 November 2021

Accepted: 7 December 2021

Published: 9 December 2021

Publisher's Note: MDPI stays neutral with regard to jurisdictional claims in published maps and institutional affiliations.

Copyright: (C) 2021 by the authors. Licensee MDPI, Basel, Switzerland. This article is an open access article distributed under the terms and conditions of the Creative Commons Attribution (CC BY) license (https:/ / creativecommons.org/licenses/by/ $4.0 /)$.

\begin{abstract}
For citrus, there is no definition of the ideal fruit harvesting point for seed extraction. Some studies have shown the positive effect of postharvest refrigerated storage of fruits to obtain quality seeds. This study aimed to evaluate the influence of the fruit maturation stage on the germination of Swingle citrumelo (CS) seeds after the refrigerated storage of fruits and seeds. CS fruits were harvested at 180 days after anthesis (DAA); 210 DAA and 240 DAA. Fruits and seeds were stored in cold chamber for $0,15,30$, and 45 days. Physicochemical analyses were performed on fruits (colour, soluble solids, acidity and ratio) and seeds (water content, germination, and emergence). Germination of seeds extracted from fruits harvested at 180, 210, and 240 DAA, without refrigerated storage, showed a positive correlation with colour index. The refrigerated storage of fruits and seeds extracted from fruits harvested at 210 DAA, increased the seed germination rate. Peel colour (IC) was correlated positively with the germination of Swingle citrumelo seeds. The results of this study revealed that the absence of refrigerated storage, harvesting Swingle citrumelo fruits, with ripe characteristics (end of harvest), results in a high seed germination rate. On the other hand, refrigerated storage of fruits and seeds extracted from fruits harvested at mid-harvest increases the seed germination rate.
\end{abstract}

Keywords: citrus; rootstock; propagation

\section{Introduction}

The seed germination rate is one of the main attributes to be considered in the implantation of a crop [1]; therefore, for several crops, there are minimum standard germination values required by law for seed marketing. In the specific case of citrus, some varieties have presented germination uniformity problems, which may be related to the harvest of immature fruits or due to seed dormancy [2]. Swingle citrumelo (Citrus paradisi Macfad. $\times$ Poncirus trifoliata L. Raf.), for example, in addition to presenting germination uniformity difficulties, also presents variations in fruit and seed maturation, and seed desiccation intolerance [3].

Swingle citrumelo is one of the preferred rootstocks used in Brazil due to its tolerance to citrus sudden death, a severe disease found in the late 1990s in the Southwestern state of Minas Gerais and Northern state of São Paulo [4]. However, nurseries have faced concerns in the production of seedling rootstocks, such as poor germination and low seed storage potential [5].

Characteristics such as the water content of seeds and morphological aspects of fruits are considered to define the harvest; however, these factors can vary depending on climatic changes at the end of the plant's cycle. The harvest of Swingle citrumelo for seed extraction, under Brazilian conditions, is concentrated in March and June, when fruits begin to change 
the skin colour from green to yellow. However, seeds are often immature, showing the importance of studying different harvesting stages [6].

Some studies have shown the positive effect of postharvest refrigerated storage of fleshy climacteric fruits (pumpkin, watermelon, papaya, eggplant, tomato, and pepper) to obtain seeds with better physiological quality, and this effect is more evident when fruits are harvested early, before complete maturation [7]. Such studies showed significant increases in the physiological quality of seeds during fruit development, being more pronounced with their colour change [8].

The physicochemical changes of Swingle citrumelo fruits during refrigerated storage that may influence the physiological quality of seeds are not fully known. In addition, the effect of refrigerated storage on bare seeds extracted from fruits harvested at different times on their physiological quality is not known. Thus, this work aimed was to evaluate the influence of the maturation stage of Swingle citrumelo fruits on the seed germination rate after refrigerated storage of fruits and bare seeds, seeking to define the ideal harvesting point of fruits and seed extraction.

\section{Materials and Methods}

\subsection{Location and Plant Material}

The research was carried out at the Seeds and Seedlings Production Unit and the Breeding Laboratory, both at the 'Sylvio Moreira' Citriculture Center, Agronomic Institute (IAC) of Cordeirópolis, state of São Paulo, Brazil and at the Plant Production and Forest Resources Teaching Laboratory belonging to the Department of Rural Development, Center for Agricultural Sciences (CCA), Federal University of São Carlos (UFSCar), Araras, state of São Paulo, Brazil. The rootstock evaluated in this research was Swingle citrumelo. The trees are located at coordinates $22^{\circ} 27^{\prime} 35^{\prime \prime} \mathrm{S}$ and $47^{\circ} 24^{\prime} 27^{\prime \prime} \mathrm{W}$, with an average altitude of $712 \mathrm{~m}$ above sea level. The climate is classified as subtropical Cwa with dry winters (temperatures below $18{ }^{\circ} \mathrm{C}$ ) and hot summers (temperatures above $22^{\circ} \mathrm{C}$ ) according to the Köppen-Geiger climate classification system [9].

\subsection{Fruit Harvest and Experimental Design}

Swingle citrumelo fruits were harvested from the middle third of the scion, sampling in the four quadrants of the plant (north, south, east, and west). The phenological stages of plants were monitored to identify the beginning of flowering (anthesis). In 2018, anthesis occurred in September, so harvest was carried out between April and June 2019 at three different maturities (A) 180 days after anthesis (DAA) (early harvest); (B) 210 DAA (midharvest), and (C) 240 DAA (end of harvest) (Figure 1). At all harvesting times, fruits were at growth stage III, that is, the ripening stage.

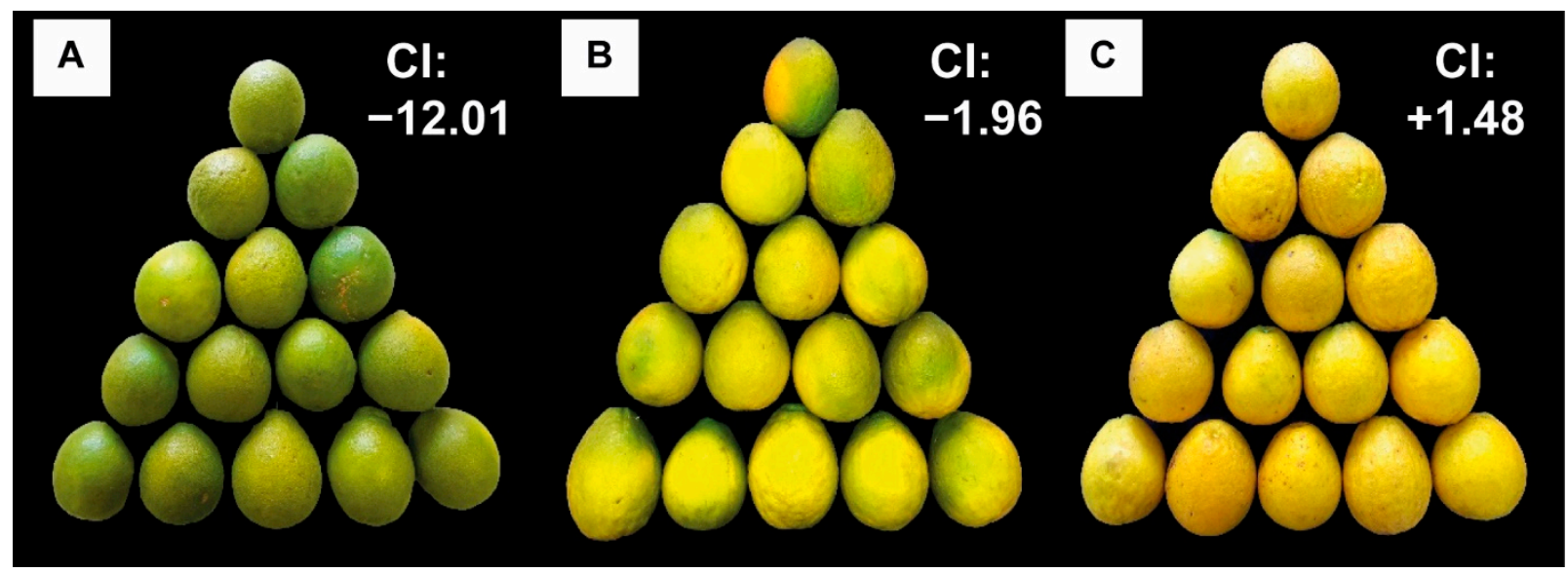

Figure 1. Swingle citrumelo fruits harvested at 180 days after anthesis (DAA) (early harvest) (A), 210 DAA (mid-harvest) (B), and 240 DAA (end of harvest) (C). CI = colour index. 
In the laboratory, 600 fruits at each harvesting time were selected, which were immersed in $1 \%$ sodium hypochlorite for three minutes. After natural drying, seeds from 300 fruits were extracted and stored in plastic bags (polyethylene) in a cold chamber at $5 \pm 2{ }^{\circ} \mathrm{C}$ and $85 \pm 3 \%$ relative humidity for $0,15,30$, and 45 days. The other 300 fruits were kept in a cold chamber in unprotected baskets for $0,15,30$, and 45 days at $5 \pm 2{ }^{\circ} \mathrm{C}$ and $85 \pm 3 \%$ relative humidity. For the storage of fruits and seeds, three replicates with 25 fruits per treatment were used.

The experiment was installed in a completely randomized design in a $3 \times 2 \times 4$ factorial scheme composed of three harvesting times $(180,210$, and 240 DAA), storage of fruits and seeds and four refrigerated storage times $(0,15,30$ and 45 days), for the evaluations of seeds. In addition to the storage of fruits for seed extraction, three replicates of five fruits in each treatment were stored for physicochemical determinations, in this case following a $3 \times 4$ factorial design, with three harvesting times (180, 210, and 240 DAA), and four refrigerated storage times $(0,15,30$, and 45 days).

\subsection{Evaluations}

2.3.1. Physicochemical Evaluations of Swingle Citrumelo Fruits and Juice Fruit Colouring

Colour was determined on the fruit peel at three stages of ripening in the equatorial region using Minolta digital colorimeter model CR 300 to establish L (colour luminosity), a (green to red colour variation), and $\mathrm{b}$ values (blue to yellow colour variation). The colour index was calculated by the formula IC $=(1000 \times a) /(b \times L)$, which values ranged from -20 to +20 (Hunter colour scale). The more negative the IC value, the greener the colour of the fruit peel, and the more positive, the more orange its colour. Zero corresponds to the yellow hue [10].

\section{Total Soluble Solids, Titratable Acidity, and Ratio}

The total soluble solids content (TSS) was determined by direct reading in B \& S refractometer model RFM 330 and expressed in ${ }^{\circ}$ Brix, according to the method described by the Official Methods of Analysis [11]. The equipment was calibrated with distilled water and then two drops of juice (sample) were placed in the optical prism to determine the reading. Data were corrected for temperature and juice acidity.

Acidity (TA) was determined by the volumetric method [11], obtained by the titration of $25 \mathrm{~mL}$ of juice with 0.3125 normality sodium hydroxide solution and phenolphthalein as indicators of the end-point. Under neutrality conditions, the sodium hydroxide solution turns the juice pink. The juice acidity was expressed as \% citric acid.

TSS and TA were used to establish the TSS/TA ratio, calculating the acidity value equal to 1.

\subsubsection{Evaluations on Swingle Citrumelo Seeds Water Content}

Before storing seeds in the cold chamber, they were manually removed from fruits and washed with water and neutral detergent at $10 \%$ concentration to remove the mucilage from the surrounding fruit. The water content of seeds was determined by the method of the oven at $105 \pm 3{ }^{\circ} \mathrm{C}$ for $24 \mathrm{~h}$, with two replicates for each sample, according to the Rules for Seed Analysis [12]. Subsequently, seeds remained to dry for about two days in the shade until reaching a water content of $40 \%( \pm 2)$ and then submitted to refrigerated storage.

For seeds extracted after storage of Swingle citrumelo fruits, extraction, washing, and water content determination were carried out as described above and before tests were carried out, water content was standardized at $40 \%( \pm 2)$, with seeds drying in the shade.

\section{Seed Germination}

Seed germination was performed, adapting the criteria established by the Rules for Seed Analysis [12]. A roll of towel paper moistened with a water volume equivalent to 
2.5 times the weight of the dry towel paper was used as substrate. For each replicate, two rolls with 50 seeds were installed, totalling six rolls per treatment. Rolls were kept in a germinator at $30{ }^{\circ} \mathrm{C}$. Evaluations were performed on the 30th day after sowing, recording the percentage of normal seedlings.

\section{Emergence in Greenhouse}

For the emergence test in a greenhouse, seeds were individually placed in tubes filled with substrates based on pine bark, in $1 \mathrm{~cm}$-deep furrow. Two samples of 50 seeds per replicate were sown, totalling 300 seeds per treatment. The substrate was moistened, always, until of capacity of retention, and the final seedling evaluation was carried out until seedling emergence stabilization, which occurred 60 days after sowing.

\subsection{Data Analysis}

Data were submitted to analysis of variance and subsequent comparison of means (Tukey, 5\%), using the ASSISTAT software [13]. As there was an interaction between factors, regressions were carried out by fixing storage times. Correlations between variables were analysed using Pearson's linear correlation test $(\alpha=0.005$ and 0.010$)$. For better visualization of relationships between the set of physicochemical variables of fruits and the physiological quality of seeds, multivariate analysis was performed using the principal component analysis (PCA) and the OriginPro software (v. 2018, OriginLab ${ }^{\circledR}$ Corp, Northampton, MA, USA) and data were standardized and demonstrated by the correlation biplot $[14,15]$.

\section{Results}

\subsection{Physicochemical Quality of Fruits}

There was a significant interaction between harvesting times (ripening stages) and storage times of Swingle citrumelo fruits in all physicochemical fruit quality variables. There was an influence of the harvesting time on the colour index (IC) of fruits, and in fruits harvested at 180 DAA and 210 DAA, an increase in IC was observed after storage in the cold chamber (Figure 2A). Fruits harvested at 180 DAA, which initially had green peel (Figure 1), presented colour index of -11.34 , reaching 0.61 at the end of 45 days of storage, which shows that there was peel pigmentation, making it more yellow. Fruits harvested at 210 DAA, which had a yellowish-green peel tone, presented an initial colour index of -1.95 , reaching 1.34 at the end of storage. Fruits harvested at 240 DAA already had ripe fruit colour (yellow) and kept the colour index constant throughout storage.

The total soluble solids content of the juice, at harvesting time 0 , from fruits harvested at different maturities were very close. On the other hand, there was variation in the soluble solids content during refrigerated storage in fruits harvested at 240 DAA (Figure 2B). The juice from fruits harvested at 180 and 210 DAA presented constant soluble solids content from the beginning to the end of storage, whereas fruits harvested at 240 DAA presented a drop of $0.50{ }^{\circ}$ Brix in the soluble solids content at the end of 45 days of storage, from $9.00{ }^{\circ}$ Brix to $8.50^{\circ}$ Brix.

The harvesting time influenced acidity in the juice of Swingle citrumelo fruits; however, there was little variation in acidity during the storage of fruits in the cold chamber (Figure 2C). For fruits harvested at 180 DAA, acidity remained constant over the 45 days. For fruits harvested at $210 \mathrm{DAA}$, there was a decrease in acidity at the end of 45 days, from 3.74 to 3.41 . For fruits harvested at 240 DAA, acidity also remained constant until the end of the experiment, presenting lower acidity to the other stages, regardless of storage time.

The harvesting time influenced the juice ratio of Swingle citrumelo fruits. Fruits harvested at 180 DAA had a juice ratio of 2.17, followed by those harvested at 210 DAA with a ratio of 2.37 and those harvested at 240 DAA, with 2.60 (Figure 2D). For fruits harvested at $180 \mathrm{DAA}$, there were no changes in the juice ratio over the 45 days of storage. In turn, fruits harvested at 210 DAA had an increase in the juice ratio, from 2.37 to 2.52 at the end of 45 days of storage. Fruits harvested at 180 DAA and those harvested at 240 DAA 
did not change the juice ratio during storage; however, values were higher compared to the other treatments.

(A)

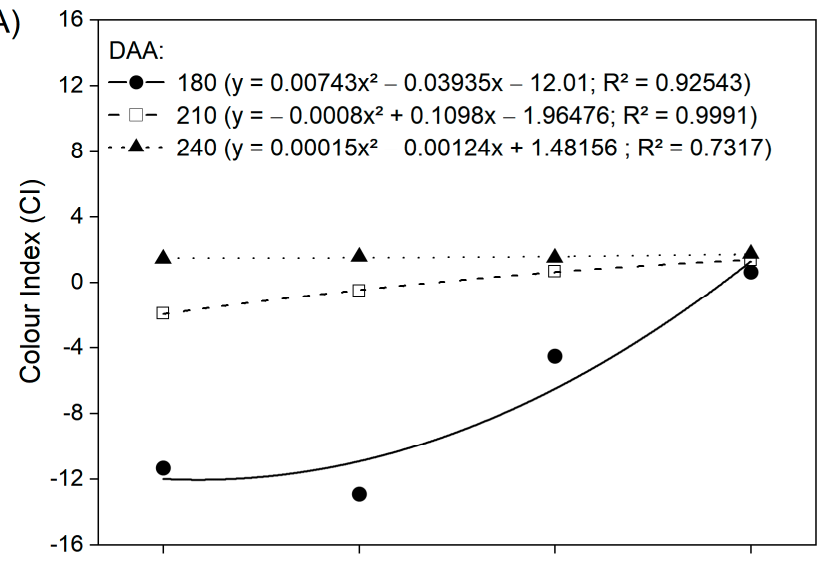

(C)

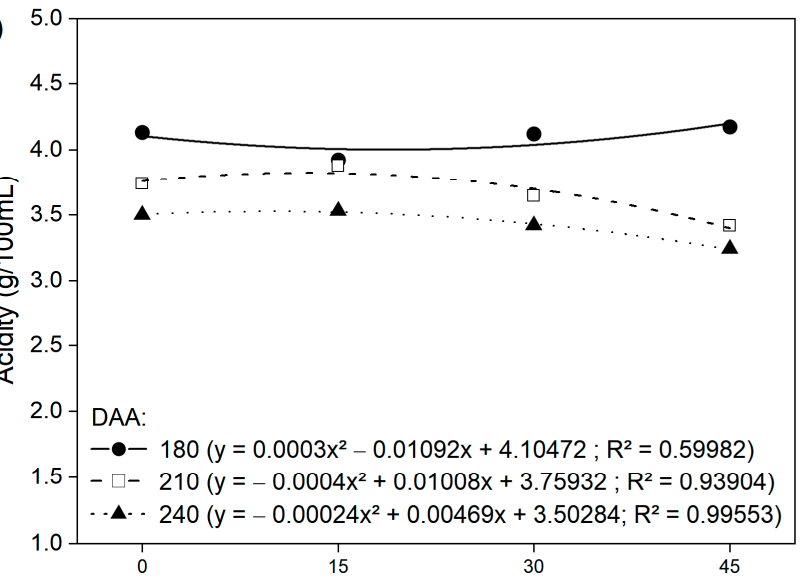

(B)

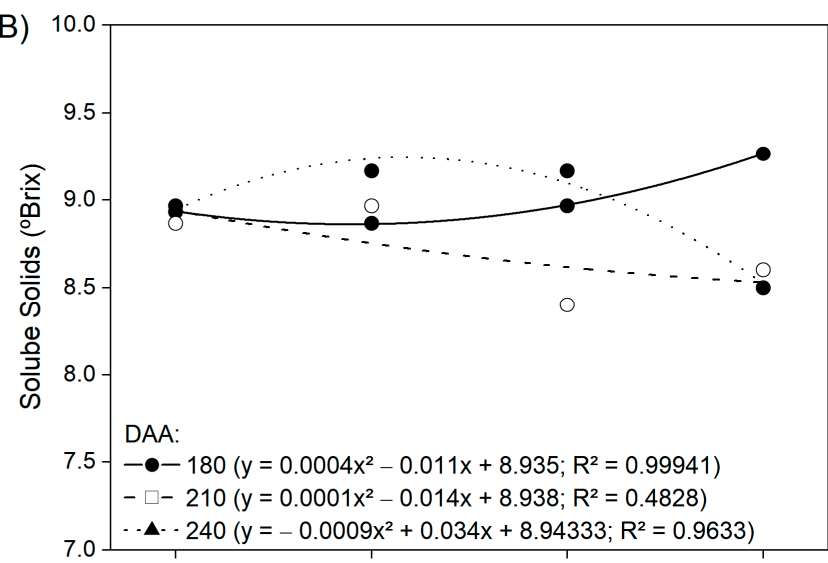

(D)

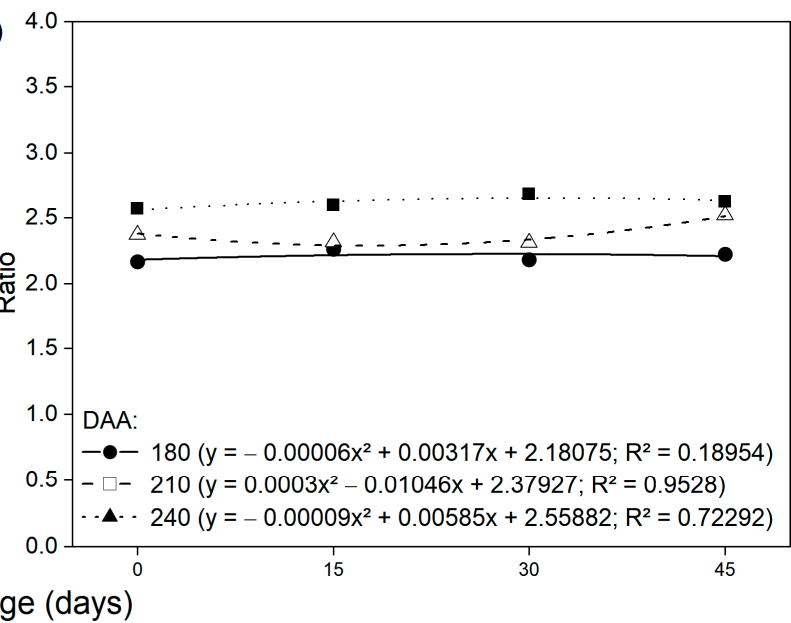

Figure 2. Fruit colour index (A), soluble solids content (B), titratable acidity (C) and juice ratio (D), of Swingle citrumelo fruits harvested at 180 days after anthesis (DAA) (beginning of harvest), 210 DAA (mid-harvest) and 240 DAA (end of harvest) stored in a cold chamber at $5 \pm 2{ }^{\circ} \mathrm{C}$ and $85 \pm 3 \%$ relative humidity for $0,15,30$ and 45 days.

\subsection{Water Content, Germination and Seed Emergence}

There was a significant interaction between harvesting times (ripening stages), types of storage (fruit or seed) and storage times (days) in water content, germination, and seed emergence evaluations.

Seeds extracted from fruits harvested at 240 DAA had the lowest initial water content, around $42 \%$ when compared to $62 \%$ for seeds extracted from fruits harvested at 180 DAA and $59 \%$ for fruits harvested at 210 DAA (Figure $3 \mathrm{~A}$ ). The same trend was observed in the initial water content of stored seeds, being $60 \%-180 \mathrm{DAA} ; 50 \%-210 \mathrm{DAA}$, and $42 \%-240$ DAA (Figure 3B).

Seeds extracted from stored fruits harvested at 180 and 210 DAA showed a decrease in water content at 15 days of storage, remaining in hygroscopic balance throughout the rest of the period (Figure 3A). The same trend was observed for bare seeds stored in plastic bags directly in a cold chamber, not being in fruits (Figure 3B). On the other hand, seeds from fruits harvested at 240 DAA did not show major changes during storage, regardless of whether they were stored bare or in fruits (Figure $3 \mathrm{~A}, \mathrm{~B}$ ). 

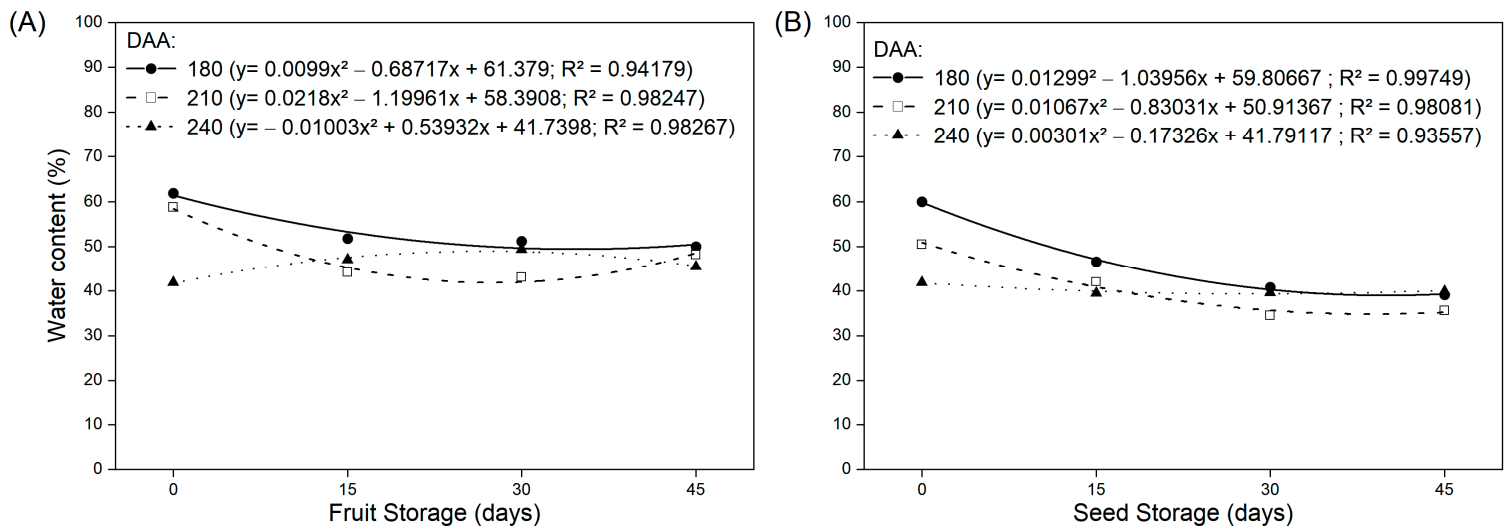

Figure 3. Water content of seeds extracted from Swingle citrumelo fruits harvested at 180 days after anthesis (DAA) (early harvest), 210 DAA (mid-harvest), and 240 DAA (end of harvest). Storage of fruits (A) and seeds (B) at $5 \pm 2{ }^{\circ} \mathrm{C}$ and $85 \pm 3 \%$ relative humidity for $0,15,30$ and 45 days.

The harvesting point influenced the initial seed germination (time 0), and seeds extracted from fruits harvested at 240 DAA presented higher initial germination compared to the other periods (Figure 4A,B). The refrigerated storage of fruits harvested at 180 DAA and 210 DAA resulted in an increase in seed germination (Figure 4A). For fruits harvested at $180 \mathrm{DAA}$, storage increased seed germination by $50 \%$, from $30 \%$ at time 0 to $80 \%$ at the end of 45 days. For fruits harvested at 210 DAA, the increase in germination was $33 \%$, from $43 \%$ to $76 \%$ after 45 days of fruit storage. The germination of seeds extracted from fruits harvested at 240 DAA showed a decrease of $35 \%$ at the end of 45 days of storage, from $51 \%$ to $16 \%$ (Figure $4 \mathrm{~A}$ ).
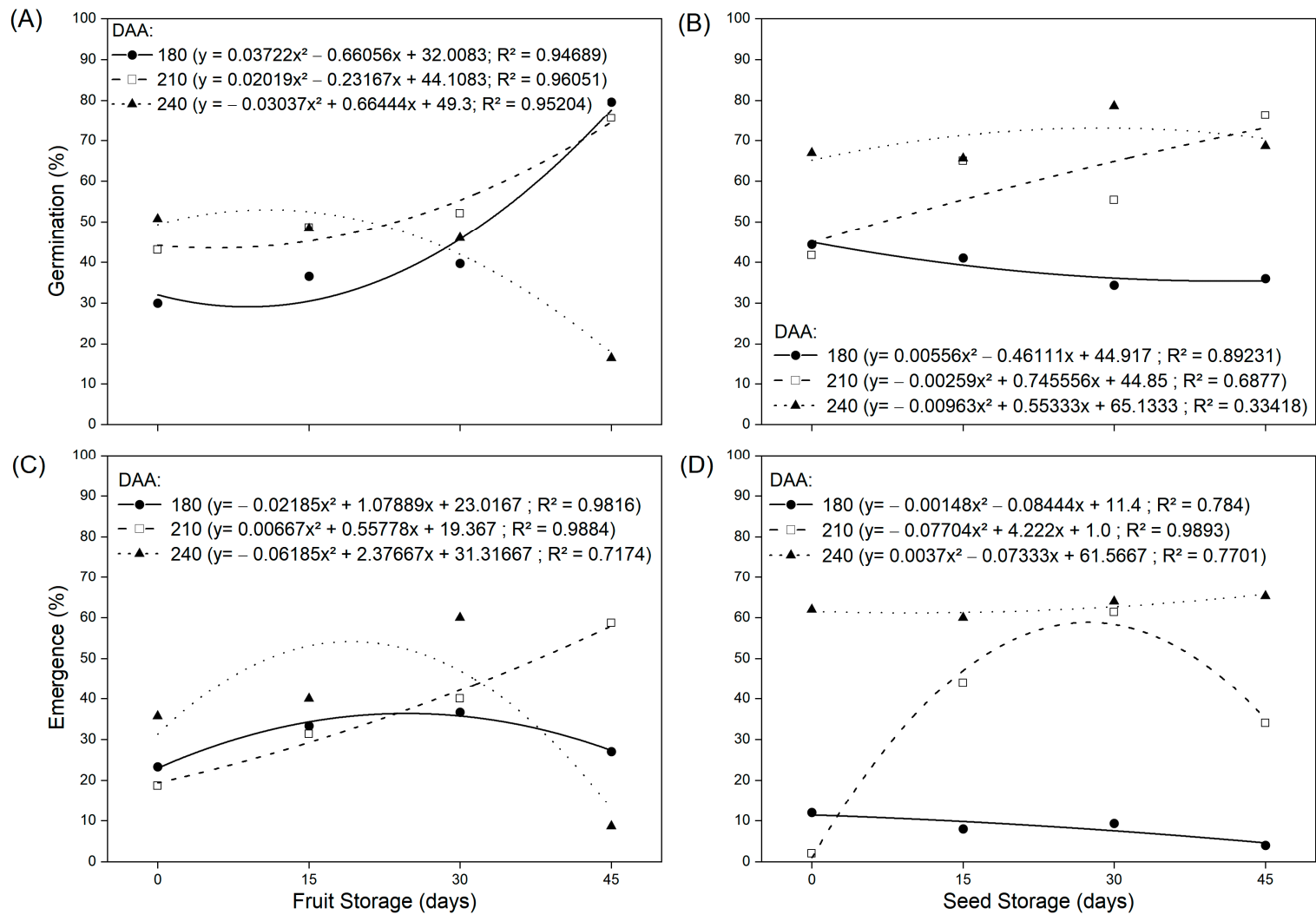

Figure 4. Germination (A,B) and emergence (C,D) of seeds extracted from Swingle citrumelo fruits harvested at 180 days after anthesis (DAA) (early harvest), 210 DAA (mid-harvest), and 240 DAA (end of harvest) after storage of fruits (A,C) and seeds $(\mathbf{B}, \mathbf{D})$ at $5 \pm 2{ }^{\circ} \mathrm{C}$ and $85 \pm 3 \%$ relative humidity for $0,15,30$ and 45 days. 
Stored Swingle citrumelo seeds extracted from fruits harvested at 180 DAA, even after 45 days of refrigerated storage, showed a low percentage of initial germination $(44 \%)$ and these values decreased to $36 \%$ at the end of storage. The storage of bare seeds extracted from fruits harvested at 210 DAA provided an increase of $34 \%$ in germination, from $42 \%$ to $76 \%$ at the end of storage, which allows marketing seeds from 15 days of storage (Figure 4B). Seeds extracted from fruits harvested at 240 DAA showed constant germination after storage ( $67 \%$ to $69 \%$ ) and can be marketed soon after extraction or kept under refrigeration for up to 45 days (Figure $4 \mathrm{~B}$ ).

The harvesting time influenced the emergence of Swingle citrumelo seedlings in the greenhouse. Seeds extracted from fruits harvested at 180 DAA and 210 DAA showed a lower emergence rate compared to those extracted from fruits harvested at 240 DAA (Figure 4C,D).

In seeds extracted from stored fruits harvested at $180 \mathrm{DAA}$, the seedling emergence rate increased from $23 \%$ to $37 \%$ at 30 days, with a small drop at 45 days of storage. For seeds extracted from stored fruits harvested at 210 DAA, an increase of $40 \%$ in seedling emergence rate was observed at the end of 45 days (Figure $4 \mathrm{C}$ ). An increase in seedling emergence rates up to 30 days was observed, with a subsequent drop in seeds extracted from stored fruits harvested at $240 \mathrm{DAA}$, reaching $60 \%$ at 30 days, but at the end of the experiment, only $9 \%$ of seedlings emerged (Figure 4 C).

For stored seeds, the emergence of those extracted from fruits harvested at 180 DAA was not influenced by refrigerated storage, as well as for seeds from fruits harvested at 240 DAA. There was a $60 \%$ increase in the emergence of seeds extracted from fruits harvested at 210 DAA with 30 days, which decreased at 45 days of storage (Figure 4D).

\subsection{Principal Component Analysis (PCA)}

Regarding PCA, the first two principal components (PC1 and PC2) represented $65.84 \%$ of the total data variance. Positive correlations were observed between germination and emergence $(r=0.4994, p<0.0019)$ and between germination and peel colour-IC $(r=0.3827$, $p<0.0213$ ), and treatments that most approximated the germination variable were fruits harvested 180 and $210 \mathrm{DAA}$, with 45 days of storage. For the emergence rate, the closest treatment was $210 \mathrm{DAA}$, with fruits being stored for 45 days (Figure 5).

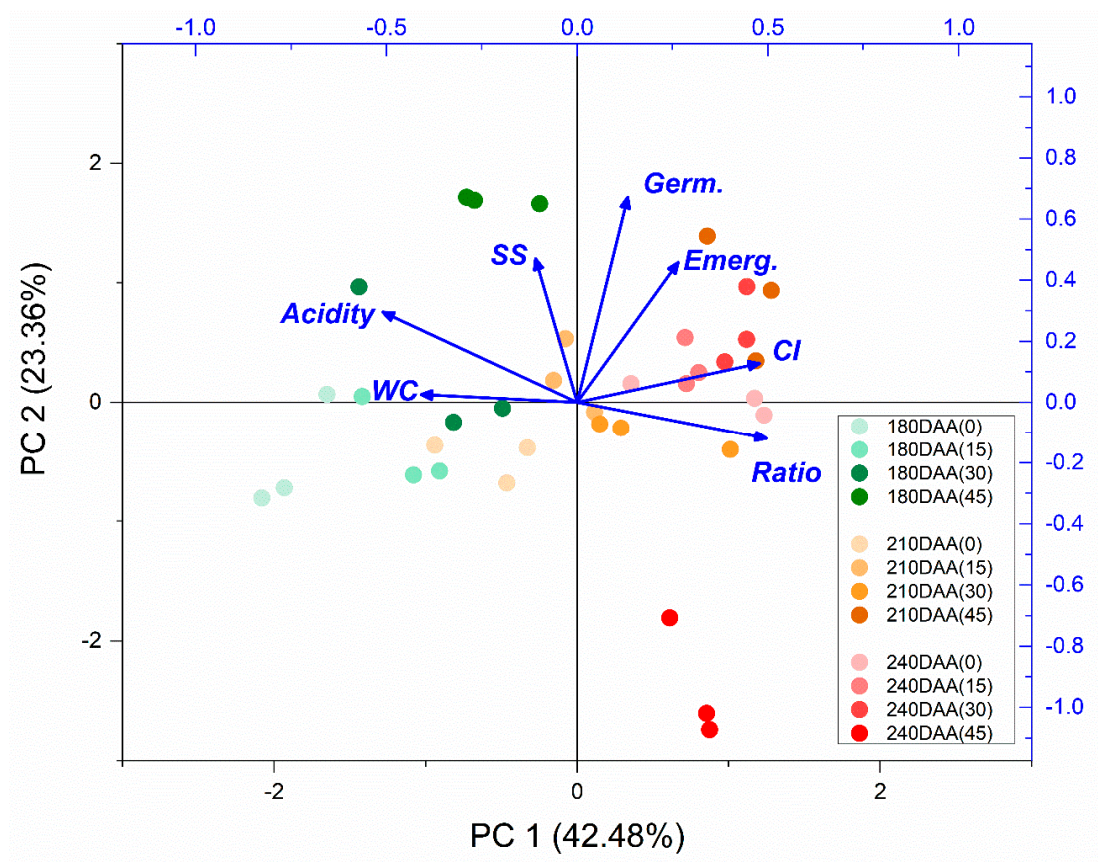

Figure 5. Principal component analysis (PC $1 \times$ PC 2 biplot) between variables of the physicochemical analyses of fruits (colour index-IC, total soluble solids-SS, acidity, and ratio), water content (WC), seed emergence, and germination. 


\section{Discussion}

\subsection{Physicochemical Evaluations of Swingle Citrumelo Fruits and Juice}

The increase in the colour index of fruits harvested at 180 DAA and 210 DAA after storage in cold chamber shows that there was peel pigmentation, making fruits more yellow, especially for fruits harvested at 180 DAA, which had green peel at harvest (Figure 2A). During citrus ripening, the most evident changes are those that occur in peel colour, as observed in this study. Fruits harvested at 240 DAA already had ripe fruit colour (yellow), thus, they kept the colour index constant throughout storage (Figure 2A).

The colour of ripe fruits is a result of the enzymatic degradation of chlorophyll, responsible for the green colour and the synthesis of carotenoids in the flavedo tissue, which provides yellow and orange colour to fruits. Cold influences the increase of carotenoid pigments in the fruit peel by accelerating the reduction of chlorophyll [16]. Thus, the peel colour may not always be related to the maturation stage, not being a good indicator alone. The physiological process that acts on the internal ripening of citrus fruits is independent of the peel pigmentation process.

For scion varieties of the genus Citrus, from the beginning to the end of the maturation stage, the levels of total soluble solids are increasing [17]. However, for Swingle citrumelo, a Citrus paradisi $\times$ Poncirus trifoliata hybrid rootstock, the same was not observed in this study (Figure 2B). In other words, maturation (harvesting time) had little influence on the soluble solids concentration. The influence of refrigerated storage on the soluble solids concentration in fruits is due to low storage temperatures, which can delay the metabolic activity, reducing the synthesis and degradation of polysaccharides and carbohydrates [18]. The soluble solids contents were not influenced by the storage time of Champagne orange variety at low temperature [19]. If soluble solids are evaluated in isolation, they are not a reliable indicator of maturation, as they cannot accurately assess the actual ripening stage of fruits [20].

The lower acidity of fruits harvested at 240 DAA, in relation to the other stages, regardless of storage period (Figure 2C), is explained by the accumulation of acids during the initial fruit development, which reaches maximum content and then begins to decrease during the ripening phase due to dilution as a function of fruit growth [20]. This reduction occurs due to the oxidation of tricarboxylic acids due to respiration or their transformation into sugars to generate energy [21]. The stability of acidity during storage is due to the growth cease caused at the time of fruit harvesting when the fruit is detached from the plant.

Fruits harvested at 240 DAA had a higher ratio compared to the other treatments, which is directly related to the maturation stage and stability of the amount of total soluble solids between harvesting times and the lower acidity of fruits harvested at 240 DAA (Figure 2D). The ratio depends on the ripening stage at which fruits were harvested and tends to increase during ripening [21]. During fruit storage, regardless of harvesting time, there were no major changes in total soluble solids, acidity, and ratio, because nonclimacteric fruits have low starch reserves, thus, these undergo few changes in internal quality during the storage period [22].

\subsection{Evaluation of Swingle Citrumelo Seeds}

In the present study, seeds from fruits stored under refrigeration remained in the hygroscopic balance due to the maintenance of moisture inside fruits (Figure 3A). In turn, the decrease in the water content of seeds stored in plastic bags (Figure 3B) can be explained by the moisture balance of seeds inside plastic bags [23]. Although the water content has decreased after storage, seeds still had water content close to $40 \%$, a value considered ideal for ensuring the maintenance of the viability of Swingle citrumelo seeds [2,24,25].

The water content is one of the indicators of the physiological maturity point of seeds and seeds contained in fleshy fruits generally do not suffer great water content fluctuations as a function of the relative air humidity. In this case, these remain with high water content "protected" inside the fruit, and under field conditions, this parameter cannot be easily 
monitored [8]. However, the water content of seeds undergoes a small increase in the initial phase of their formation to facilitate the deposition of assimilates and decreases with the increase in deposition until the physiological maturity point, which is mainly observed in ripe fruits harvested at 240 DAA.

The greater germination of seeds extracted from fruits harvested a 240 DAA (Figure 4A,B) shows that seeds extracted from riper fruits have higher initial quality (time 0 ); in addition, the fruit maturation process observed by changes in physicochemical characteristics during storage, mainly in fruits harvested at 180 DAA and 210 DAA, increased the seed germination rate and the highest germination rate was observed in seeds extracted from fruits whose physicochemical results were high. PCA confirms the correlation of some variables with germination, the increase in the physiological quality of seeds after storage of fruits harvested at $180 \mathrm{DAA}$ and $210 \mathrm{DAA}$ for up to 45 days, and the negative relationship between seed germination and fruits harvested at 180 DAA without cold storage (Figure 5).

Fruits harvested at 240 DAA showed little physicochemical changes during storage, as they were harvested at a more advanced maturation stage. In addition, they should not be stored, as they showed a drop in seed germination during refrigerated storage (Figure 4A), which indicates deterioration of fruits and, consequently, of seeds [26].

The greater germination rate of seeds from ripe fruits compared to those from unripe fruits soon after harvest because seeds go through a series of morphological, physiological, and functional transformations until physiological maturity is reached when the translocation of assimilates from plant to seeds ceases [25,27]; and for fleshy fruit species, maturation coincides with changes in peel colour. This indicates the harvest of fruits with approximate colour index values above 1.49 .

The increase in seed germination rate after storage of fruits harvested at 180 and 210 DAA is related to the completion of the seed maturation process within the fruit and seed dormancy break, like related to pepper [28]. This fact is also observed in fleshy fruits species, such as peaches when they undergo a period of rest after harvest between 7 to 10 days before seed extraction. Thus, still immature seeds complete their development [8]. Research evaluating the physiological quality of Rangpur lemon seeds also observed an increase, in the order of $20.75 \%$, in the seed germination rate after 45 days of refrigerated storage [29].

According to Brazilian legislation, which requires at least 50\% germination for the marketing of citrus seeds, the results indicate that seeds extracted from fruits harvested at 180 DAA can only be marketed close to 45 days of refrigerated storage. Seeds extracted from fruits harvested at 210 DAA can be marketed after 30 days of refrigerated storage; on the other hand, fruits harvested at 240 DAA should not be stored. Stored Swingle citrumelo seeds extracted from fruits harvested at 180 DAA do not meet the minimum germination rate required by legislation, even after 45 days of refrigerated storage (Figure $4 \mathrm{~A}$ ), showing that cold did not influence seed germination rate at this stage, as they are extracted from completely immature fruits.

The increased germination rate of stored seeds, when extracted from fruits harvested at $210 \mathrm{DAA}$, is probably due to the seed dormancy break caused by increased cold. Some citrus rootstock varieties such as Swingle citrumelo, have some kind of dormancy, presenting uneven germination. Storage at low temperatures can influence the concentration of gibberellin (GA) and abscisic (ABA) acids inside seeds, regulating physiological dormancy and germination [30]. Under low-temperature conditions, there may be a decrease in ABA and an increase in GA, favouring seed germination [31].

Furthermore, after 15 days of storage, seeds reached the minimum percentage required for marketing, which increased up to 45 days. On the other hand, seeds extracted from fruits harvested at 240 DAA can be marketed soon after extraction and can also be stored for up to 45 days in a cold chamber. The percentage of seeds able to germinate increases during maturation, reaching a maximum value at the physiological maturity point [8].

The seed germination rate increases during maturation, reaching a maximum level at the point when seeds reach physiological maturity, which explains the fact that seeds 
extracted from fruits harvested at 240 DAA have a higher initial germination rate. However, the drop in the germination rate, after 30 days of storage of fruits harvested at 240 DAA, indicates the deterioration of fruits and, consequently, of seeds, impairing germination [8].

Germination rate data observed in this work are considered low compared to seed germination to produce seedlings in nurseries, which can be attributed to the presence of the seed coat, defined as integumentary dormancy, that is, the presence of physical barrier caused by the seed coat, requiring the use of techniques that allow seed coat wear and stimulation of the germination process [32]. Rates of germination above $80 \%$ of Swingle citrumelo are obtained with the removal of the seed coat [33]. This is because it can be an obstacle to embryonic growth, regulating the availability of water for imbibition, interfering with gas exchange and the output of inhibiting substances from the embryo, forming a barrier between the embryo and the environment [30]. In addition, the nurseryman used more than one seed per tube to propagate citrus rootstocks, which guarantees high germination rates.

Trifoliate orange seeds and their hybrids, such as Swingle citrumelo, are more sensitive to storage than other rootstocks used in the production of citrus seedlings [33]; and can be considered recalcitrant [34]; that is, intolerant to desiccation and with short longevity, in contrast to orthodox ones [35]. This concept is also accepted by many authors, adding the category of intermediates, which would also be intolerant to drying up to $10 \%$ of water [36].

Additionally, it should be considered that there is no need for the storage of citrus seeds for a long period, since citrus plants present at least one annual flowering and fruit production cycle [37]; therefore, after 12 months, new seed lots would already be available. As a result, in Brazil, it is common for nurserymen not to store seeds for long periods, but they can be stored for more than 6 months.

In general, the seedling emergence rate differed from germination results probably due to the environmental conditions of the laboratory, which are the most suitable for the species, which does not occur under field conditions, leading to lower values. Furthermore, similarly to germination rate results, emergence rate was also considered low, being attributed to integumentary dormancy. Storage of fruits and seeds increased the vigor of seeds extracted from fruits harvested at 210 DAA (Figure 4C,D).

\section{Conclusions}

Peel colour (IC) was correlated positively with the germination of Swingle citrumelo seeds. Thus, Swingle citrumelo fruits with ripe fruit characteristics (end of harvest) should be harvested, aiming at a higher germination rate in relation to early and mid-harvest fruits, without cold storage.

Cold storage ( $5 \pm 2{ }^{\circ} \mathrm{C}$ and $85 \pm 3 \%$ relative humidity) of fruits and seeds extracted from fruits harvested at 210 DAA (mid-harvest) increases the seed germination rate.

Author Contributions: F.A.d.A. and P.M.d.C. designed and performed the experiment, M.M., A.J.B.d.S. and R.M. performed, collected and analysed data; F.A.d.A., P.M.d.C., M.M., A.J.B.d.S. and R.M., critically revised and edited the final manuscript version. All authors have read and agreed to the published version of the manuscript.

Funding: This research was funded by Fundação de Amparo à Pesquisa do Estado de São Paulo (FAPESP, Brazil), grant number \#2014/16548-8 and Conselho Nacional de Desenvolvimento Científico e Tecnológico (CNPq, Brazil).

Informed Consent Statement: Informed consent was obtained from all subjects involved in the study.

Data Availability Statement: The datasets generated during and/or analyzed during the current study are available from the corresponding author on reasonable request.

Acknowledgments: To São Paulo Research Foundation-FAPESP, Brazil, that supported this study. FAA acknowledges the National Council for Scientific and Technological Development (CNPq, Brazil) for fellowships granted. 
Conflicts of Interest: The authors declare that the research was conducted in the absence of any commercial or financial relationships that could be considered as a potential conflict of interest.

\section{References}

1. Peske, S.T.; Villela, F.A.; Meneghello, G.E. Sementes: Fundamentos Científicos e Tecnológicos, 2nd ed.; UFPel: Pelotas, Brazil, 2012; 573 .

2. Gomes-Junior, F.G.; Arruda, N.; Marcos-Filho, J. Swingle citrumelo seed vigor and storability associated with fruit maturity classes based on RGB parameters. Sci. Agric. 2017, 74, 357-363. [CrossRef]

3. Gonçalves, B.H.L.; Liberato, E.M.S.; Leonel, S.; Modesto, J.H.; Souza, J.M.A. Efeito do uso de reguladores vegetais na germinação das sementes de citrumelo Swingle. Sci. Plena 2013, 9, 1-7.

4. Gimenes-Fernandes, N.; Bassanezi, R.B. Integrated management of citrus diseases: Sudden death. Fitopatol. Bras. 2003, 28, 66-72.

5. Rodrigues, F.A.; Freitas, G.F.; Moreira, R.A.; Pasqual, M. Characterization of fruits and seeds germination of rootstock trifoliata Flying Fragon and citrumelo Swingle. Rev. Bras. Frutic. 2010, 32, 1180-1188. [CrossRef]

6. Conceição, P.M.; Azevedo, F.A.; Souza, A.J.B.; Próspero, A.G.; Morelli, M.; Forti, V.A. Ideal harvesting point of ‘Limeira-IAC382 trifoliate orange fruits for seed extraction. Rev. Bras. Frutic. 2020, 42, 1-9. [CrossRef]

7. Justino, E.V.; Boiteux, L.S.; Fonseca, M.E.N.; Filho, J.G.S.; Nascimento, W.M. Determinação da maturidade fisiológica de sementes de pimenta dedo de moça Capsicum baccatum var. pendulum. Hortic. Bras. 2015, 33, 324-331. [CrossRef]

8. Pereira, F.E.C.B.; Salvadora, B.T.; Silva, M.I.L.; Grangeiro, L.C.; Benedito, C.P. Qualidade fisiológica de sementes de pimenta em função da idade e do tempo de repouso pós-colheita dos frutos. Rev. Ciênc. Agron. 2014, 45, 737-744. [CrossRef]

9. Alvares, C.A.; Stape, J.L.; Sentelhas, P.C.; de Moraes, G.; Leonardo, J.; Sparovek, G. Köppen's climate classification map for Brazil. Meteorol. Z. 2013, 22, 711-728. [CrossRef]

10. Jimenez-Cuesta, M.; Cayuela, J.C.; Martinrez-Javega, J.M. Teoria y Practica de la Desverdizacion de los Citricos; Ministerio de Agricultura, Pesca y Alimentación-INIA: Madrid, Spain, 1983; p. 22.

11. Association of Official Analytical Chemistry (AOAC). Official Methods of Analysis, 17th ed.; AOAC: Gaithersburg, MD, USA, 2000; p. 1928.

12. do Brasil, F.; Brasília, D.F.; Ministério da Agricultura, Pecuária e Abastecimento. Secretaria de Defesa Agropecuária. Regras Para Análise de Sementes; MAPA/ACS: Brasília, Brazil, 2009; p. 399.

13. Silva, F.A.S.; Azevedo, C.A.V. The Assistat Software Version 7.7 and its use in the analysis of experimental data. Afr. J. Agric. Res. 2016, 11, 3733-3740.

14. Zuur, A.F.; Ieno, E.N.; Smith, G.M. Principal component analysis and redundancy analysis. In Analysing Ecological Data; Springer: New York, NY, USA, 2007.

15. Balzarini, M.; Di Rienzo, J.; Tablada, M.; Gonzales, L.; Bruno, C.; Córdoba, M.; Robledo, W.; Casanoves, F. Estadística y Biometría, 2nd ed.; Universidad Nacional de Cordoba: Córdoba, Argentina, 2017.

16. Kluge, R.; Jomori, M.L.L.; Sasaki, F.F.C.; Berno, N.D.; Gimenes, L.C. Desverdecimento e armazenamento refrigerado de tangor 'Murcott' em função de concentração e tempo de exposição ao etileno. Semin. Ciênc. Agrár. 2014, 35, 825-834. [CrossRef]

17. Sartori, I.A.; Koller, O.C.; Schwarz, S.F.; Bender, R.J.; Schäfer, G. Maturação de frutos de seis cultivares de laranjas-doces na depressão central do Rio Grande do Sul. Rev. Bras. Frutic. 2002, 24, 364-369. [CrossRef]

18. Chitarra, M.I.F.; Chitarra, A.B. Pós-Colheita de Frutas e Hortaliças: Fisiologia e Manuseio, 2nd ed.; UFLA: Lavras, Brazil, $2005 ;$ p. 786

19. Agostini, J.S.; Scalon, S.Q.; Lescan, C.H.; Silva, K.E.; Garcete, G.J. Nota Científica: Conservação pós-colheita de Laranjas Champagne (Citrus reticulata $\times$ Citrus sinensis). Braz. J. Food Technol. 2014, 17, 177-184. [CrossRef]

20. Koblitz, M.G.B. Matérias-Primas Alimentícias: Composição e Controle de Qualidade; Guanabara Koogan: Rio de Janeiro, Brazil, 2014.

21. Almeida, M.B. Determinação do Estádio Ótimo de Maturação a Colheita do Limão "Siciliano", Produzidos no Estado do Ceará. Master's Thesis, Universidade Federal do Ceará, Fortaleza, Brazil, 2014.

22. Adams, C.R.; Klein, C. Uso de Biofilmes na Conservação Pós-Colheita de Lima-da-Pérsia (Citrus Limettioides Tanaka); Unoesc CiênciaACET: Santa Catarina, Mexico, 2018; Volume 9, pp. 85-92.

23. Carvalho, J.A.; Pinho, E.V.R.; Oliveira, J.A.; Guimarães, R.M.; Bonome, L.T. Qualidade de sementes de limão Cravo (Citrus limonia Osbeck) durante o armazenamento. Rev. Bras. Sementes 2002, 24, 286-298. [CrossRef]

24. Struving, T.B.; Machado, D.L.M.; Santos, D.; Siqueira, D.L.; Lucena, C.C.; Matarazzo, P.H.M. Qualidade fisiológica de sementes de citros durante o armazenamento em ambiente refrigerado. Ciênc. Rural. 2013, 43, 1777-1782. [CrossRef]

25. Silva, T.T.A.; Guimarães, R.M.; von Pinho, E.V.R.; Abreu, L.A.S. Storage of 'Swingle' citrumelo seeds in different maturation stages subjected to fungicide treatment. Rev. Bras. Sementes 2011, 33, 768-776. [CrossRef]

26. Ricci, N.; Pacheco, A.C.; Conde, A.S.; Custódio, C.C. Qualidade de sementes de pimenta jalapenho em função da maturação e tempo de permanência nos frutos. Pesqui. Agropecu. Trop. 2013, 43, 123-129. [CrossRef]

27. Carvalho, N.M.; Nakagawa, J. Sementes: Ciência, Tecnologia e Produção, 4th ed.; Funep: Jaboticabal, Brazil, 2000.

28. Pinheiro, D.T.; Oliveira, R.M.; Silveira, A.S.; Léon, M.J.Z.; Brum, L.B.T.L.; Dias, D.F. Antioxidant enzyme activity and physiological potential of Capsicum baccatum var. baccatum seeds as a function of post-harvest storage of fruit. J. Seed Sci. 2020, 42, 1-13. [CrossRef]

29. Morelli, M.; Azevedo, F.A.; Conceição, P.M.; Souza, A.J.B. Maturation and physiological quality of IAC-863 Rangpur lime seeds. Comun. Sci. 2019, 10, 454-460. [CrossRef] 
30. Oliveira, R.P.; Scivittaro, W.B. Formação do porta-enxerto Trifoliata: Época de semeadura e tegumento na emergência de plântulas. Ciênc. Rural. 2007, 37, 281-283. [CrossRef]

31. Cardoso, V.J.M. Germinação. In Fisiologia Vegetal, 2nd ed.; Kerbauy, G.B., Ed.; Guanabara Koogan: Rio de Janeiro, Brazil, 2012; pp. 384-408.

32. Baskin, C.C.; Baskin, J.M. Seeds: Ecology, Biogeography and Evolution of Dormancy and Germination, 2nd ed.; Academic Press: Cambridge, MA, USA, 2014.

33. Carvalho, S.A.; Silva, L.F.C. Monitoring the viability of citrus rootstocks seeds stored under refrigeration. Rev. Bras. Frutic. 2013, 35, 238-245. [CrossRef]

34. Saipari, E.; Goswami, A.M.; Dadlani, M. Effect of seed drying on germination behavior in citrus. Sci. Hortic. 1998, 73, 185-190. [CrossRef]

35. Roberts, E.H. Predicting the storage life of seeds. Proceedings 1973, 1, 499-514.

36. Usberti, R.; Roberts, E.H.; Ellis, R.H. Prediction of cottonseed longevity. Pesq. Agropec. Bras. 2006, 41, 1435-1441. [CrossRef]

37. Reuther, W. Climate and citrus behavior. In The Citrus Industry; University of California Press: Berkeley, CA, USA, 1973; Volume 3, pp. 280-337. 